\title{
Improvement of the Water Management by Applying the No Tillage System for the Winter Wheat Production
}

\author{
Felicia CHEȚAN ${ }^{*}$, Cornel CHEȚAN ${ }^{1}$
}

${ }^{1}$ Agricultural Research and Development Station, Agriculturii 27, Turda, Cluj County, Romania
${ }^{*}$ Corresponding author: F. Chețan e-mail: felice_fely@yahoo.com

RESEARCH ARTICLE

\begin{abstract}
The Transylvanian Plain has a particular aspect, as the hilly areas are predominant and here the soil erosion phenomena through levigation are frequently encountered. The effect of water availability on yields has been thoroughly researched, being one of the main limitative factors of the winter wheat yields. Starting from these considerations, during the agricultural years 2012-2018, a bi-factorial yield test was performed at Agricultural Research and Development Station (ARDS) Turda, for a period of seven years. The study explored the influence of the water status under the influence of two tillage systems and the climatic conditions specific for this area on winter wheat yields. In the field conditions of Turda during experimental interval, the soil tillage system had a rather small impact on the winter wheat yields. In the conventional system (CS) a reserve of accessible water is preserved better during the spring period, this being attributed to a better infiltration into the soil of winter precipitation (snow). In the conservative system (NT), the observed trend suggests that restoration of the ground water reserve is more difficult than in the CS but the loss of water in the CS is just as fast.
\end{abstract}

Keywords: climate; no tillage; winter wheat; water reserve; yield.

Received: 02 October 2020 Accepted: 13 May 2021

Published: 15 May 2021

DOI:

10.15835/buasvmcn-agr:2020.0040

(c) (1) (3) (ㄱ) 2021 Authors. The papers published in this journal are licensed under the Creative Commons Attribution-NonCommercialNoDerivatives 4.0 International License

\section{INTRODUCTION}

Excessive mechanical mobilization of the soil with machinery mainly through the basic soil preparation for crops causes negative consequences for soil reflected by greater water loss, a weaker mineralization of the vegetation litter, the formation of the hard pan, breakage of the capillarity continuity, and in the case of slopes also it favors erosion (Guş, 1983; Phillips and Phillips,1984; Bogdan et al., 2007; Cociu, 2011; Ibanez et al., 2008; Moraru and Rusu, 2010; Pop et al., 2013). In the last years there have been growing drought concerns, and thus there is an increased awareness of the real necessary to conserve water in the soil. In this regard it has been recognized that the choice of equipment range and technologies have the most important role (Rusu et al., 2014). Limiting the effects of the drought can also be achieved by agro-technical measures for improved retention, preservation and efficient use of precipitation water. By protecting the soil with vegetal debris (mulch) it is avoided the water loss through evaporation, while also ensuring weed suppression (Rusu, 2005; Cheţan et al., 2016). The land degradation from the Transylvanian Plain and its effects must be regarded from the point of view of the local physical-geographical conditions, over which extreme climate conditions superpose. These conditions create in general a frame favorable for the development of morphogenetic processes caused by human activity, besides just like those caused by natural mechanisms, intensifying both the rhythm and their territorial extension. 
During months of March-November the agricultural soil undergoes pressures caused by various agro-technical works, it is subject to relatively high quantity of rainfall which causes runoff on slopes ( $40-50 \%$ of the total rainfall), and on the other it is influenced by aggressive torrential rains. Together with rainfall, the landforms are also important. Characteristics of land formations that can adversely affect the soil water status are: increased degree of fragmentation, slope angle, southern-facing slopes, vegetation by the predominance of cultivated plants, advanced stage of land degradation and lithology by the predominance of friable rocks (sands, bedrocks, freestones etc.). The climate characteristics impose special technological measures for preserving the quality of land. The interaction of environmental factors with the anthropic influence has an impact upon the land state, with a lot of soils degraded by erosion, which impose restrictions regarding the crop structure, the system of machines and tractors which ensure the crop mechanization on slopes (ARDS Turda, 2008).

The purpose of this research was to study under the pedo-climatic conditions from the Transylvanian Plain the influence of the soil tillage system (classic and no-tillage) on the retention and conservation of water in the soil and the relationship with winter wheat yield.

\section{MATERIALS AND METHODS}

The research was carried out in a bi-factorial design, during the period 2012-2018 at Turda, the experimental field being included in a three-year crop rotation: soybean - winter wheat - maize. The overall surface of the trial was of $0.35 \mathrm{ha}$, and the design was a split plot with three replicates (blocks). Each block was divided into three plots with a surface of $1152 \mathrm{~m}^{2}$, corresponding to each crop of the rotation, each plot was divided into two sub-plots corresponding to the soil tillage systems. Therefore, there were three sub-plots in three replicates in the classic tillage system (conventional wheat, maize and soybean) and three in the conservative system (no-tillage wheat, minimum tillage maize and minimum tillage soybean), with a surface of $576 \mathrm{~m}^{2}$.

The experiment was conducted on phaeozem (SRTS, 2012), with clay-clay texture, good hydrophobic properties, $59 \%$ porosity on the surface and $47 \%$ in depth, high water retention capacity of $32 \%$ and Co $18 \%$; with the following agrochemical indices (MESP, 1987): $\mathrm{pH}$ 7.00; humus 2.94\%; total nitrogen 0.162\%; phosphorus 9 ppm; potassium $140 \mathrm{ppm}$ (values determined at the depth of 0 - $40 \mathrm{~cm}$ in soil).

Seeding of wheat in no-till system, as well as in the ploughed field, was performed with the GASPARDO Directa400 seeding machine, at the same sowing density of 550 germinating grains $/ \mathrm{m}^{2}, 18 \mathrm{~cm}$ distance between the rows, the seed being treated with product based on imidacloprid $233 \mathrm{~g} / \mathrm{L}+$ tebuconazole $13 \mathrm{~g} / \mathrm{L}$. The fertilization level was N70P40 (basic fertilization with N40P40 at sowing + N30 on the vegetation) when vegetation started in spring. The biological material chosen for this trial was represented by the winter wheat cultivar 'Arieşan'.

The experimental factors were:

A - Soil working system:

- $\quad a_{1}$ - classic (CS), Kuhn Huard Multi Master 125T plow with $30 \mathrm{~cm}$ depth + seedbed preparation in spring with rotary harrow HRB 403 D + sowing + fertilized with the Gaspardo Directa-400 seed drill;

- $\quad$ a2 - no-tillage (NT), direct sowing + fertilized with the Gaspardo Directa-400 seed drill.

$\mathrm{B}$ - The agricultural year, characterized by different climatic conditions:

- $b_{1}-2012 ; b_{2}-2013 ; b_{3}-2014, b_{4}-2015, b_{5}-2016, b_{6}-2017, b_{7}-2018$.

The agricultural crops in the area are mainly infested with weed species: Convolvulus arvense, Polygonum convolvulus, Cirsium arvense, Rubus caesius, Taraxacum officinalis, Viola arvensis, Agropyron repens, Xanthium strumarium, Erigeron canadensis, Setaria glauca etc. For these weeds for winter wheat crop were applied treatments on vegetation: amidosulfuron $100 \mathrm{~g} / \mathrm{L}+$ iodosulfuron-metyl-Na $25 \mathrm{~g} / \mathrm{L}+$ mefenpyr dietyl $250 \mathrm{~g} / \mathrm{L}$ (safener) + 660 $\mathrm{g} / \mathrm{L}$ acide dimethyl amine salt.

The determination of the soil moisture at depth of 0-50 cm was conducted according to the gravimetric method (taking soil samples with Theta drill and drying them in the oven at $108^{\circ} \mathrm{C}$ for 8 hours).

The yield of the wheat crop was determined by weighting production from the experimental plots, after eliminating the sides and correcting the production according to STAS moisture (14\%). The experimental data were statistically analyzed using the Least Significant Difference test - LSD (5\%, 1\%, and 0.1\%) (ANOVA, 2015).

\section{RESULTS AND DISCUSSIONS}

The results obtained have to be put in relation with the dynamic of the climatic factors in order to identify the best agrotechnical measures for adapting to climate changes. In this regard, it is required to analyze the evolution of the thermal and rainfall regime registered during the experimental interval at Agricultural Research and Development Station from Turda in comparison to the average for the last 62 years, respectively the dynamics since 1957 date when the station was set up (Figure 1 and 2). The research area is characterized by a multiannual average temperature of $9.1^{\circ} \mathrm{C}$ and by multiannual average rainfall of $531 \mathrm{~mm}$. But during the last years one can notice a clear trend of increasing temperatures and decrease of the rainfall recorded. 


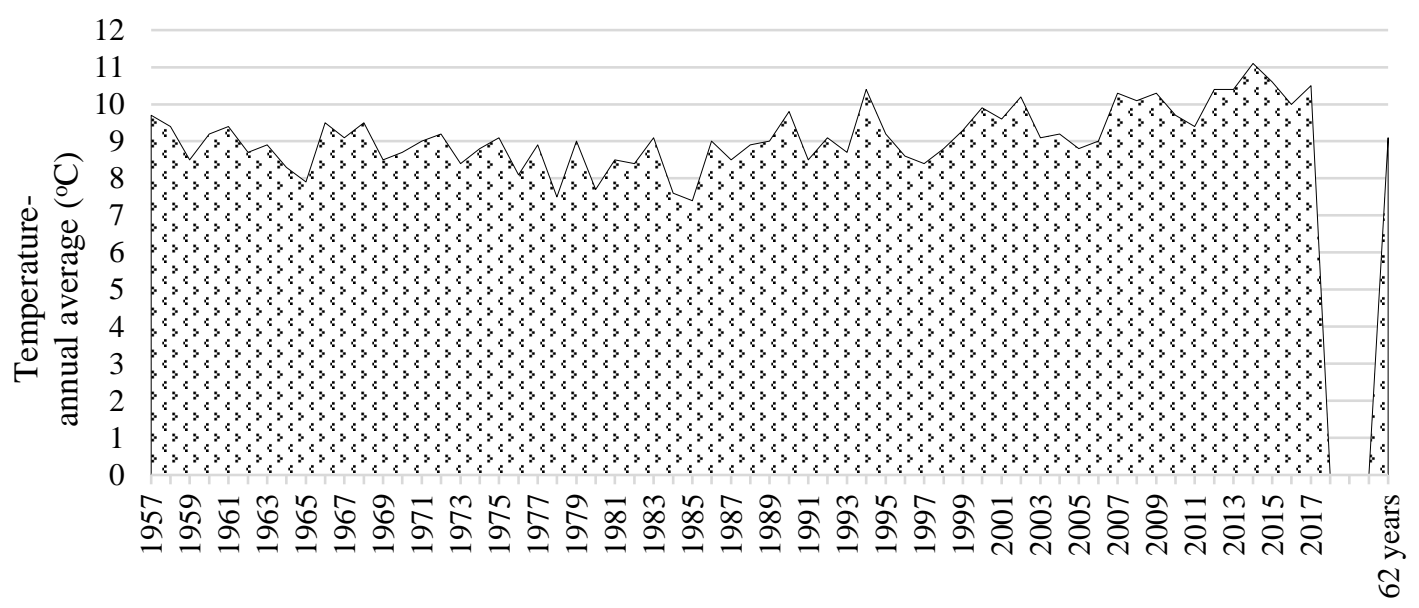

Figure 1. Temperature during 1957-2018 at ARDS Turda (measured by Turda Meteorological Station, $23^{\circ} 47^{\prime}$ longitude; $46^{\circ} 35^{\prime}$ latitude; 427 m altitude)

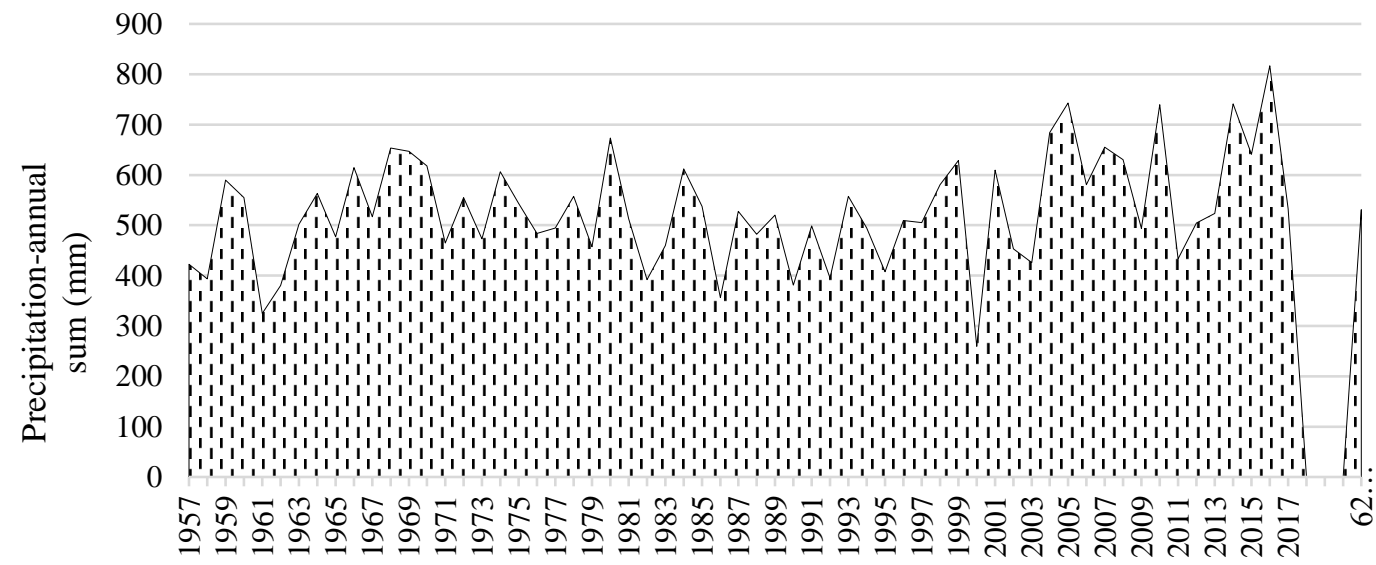

Figure 2. The rainfall during 1957-2018 at ARDS Turda (measured by Turda Meteorological Station, $23^{\circ} 47^{\prime}$ longitude; $46^{\circ} 35^{\prime}$ latitude; $427 \mathrm{~m}$ altitude)

Specific for the seven years that were part of the current research (2012-2018) was the unequal distribution of rainfall; there were periods of drought, with extended pedologic drought followed by torrential rain. April and May of 2012 were warm, and during June-August there was a heat wave that lasted for 21 days in a row; during this period temperatures exceeded $32^{\circ} \mathrm{C}$, and the biological processes of the plants were affected. Considering the rainfall one can argue that all months of that year were droughty. The rainfall from the months of April and May somehow restored the water reserve in the soil, which helped plants make good productions.

Specific for 2013 was the alternation of heat waves with periods of cool temperatures, with high differences from one interval to another, which resulted in the disturbance of biological cycles for certain species of plants. The temperature values deviated from multiannual average by +2.1 up to $+2.5^{\circ} \mathrm{C}$, generating three warm months Months of April and May registered thermal values exceeding $29^{\circ} \mathrm{C}$. During summer, compared to the monthly multiannual average, thermal values exceeded the multiannual average by +1.7 in July and respectively by $+2.9^{\circ} \mathrm{C}$ in August, the months being predominantly warm, the maximum values of temperature exceeded many times the heat threshold. The end of July - beginning of August recorded seven days of continuous heat and corroborated with relatively very low moisture (around 20-29\%) this caused the onset of a stabilized atmosphere drought. The highest value of temperature was $+35.8^{\circ} \mathrm{C}$ on 9.08 .2013 . In July and August, cured a strong drought which caused stress to plants, intensive rain came late, at the end of August, after 25.08.2013.

From a climate point of view, 2014 was a favorable year for agricultural crops, the alternation of months with normal temperatures from a thermal point of view with hot ones was beneficial for the ongoing of vegetative steps. The rainfall from 2014 with the annual amount of $741.5 \mathrm{~mm}$ was quantitatively high, especially in the summer, even if the number of rainy days was smaller. The year 2015 was warm and rainy. The annual average was $10.6^{\circ} \mathrm{C}$, that 
is $1.5^{\circ} \mathrm{C}$ higher than the multiannual average in 62 years. The rainfall of this year exceeded by $122.4 \mathrm{~L} / \mathrm{m}^{2}$ the multiannual average of 62 years $\left(531 \mathrm{~L} / \mathrm{m}^{2}\right)$.

The year 2016 was a warm, with a deviation of $+0.9^{\circ} \mathrm{C}$ compared to the multiannual average, recording an annual average temperature of $10^{\circ} \mathrm{C}$. From the point of view of the rainfall regime, with $816.8 \mathrm{~L} / \mathrm{m}^{2}$ and a deviation of +288 $\mathrm{L} / \mathrm{m}^{2}$ compared to the multiannual average is characterized as an excessively rainy year.

Year 2017 began with a cold month compared to multiannual average, followed by two warm months: February and March. The spring months of April and May were characterized as having normal thermal temperatures, followed by a warm summer (June $+2.8^{\circ} \mathrm{C}$, August $+3^{\circ} \mathrm{C}$ ) and a normal July month with a deviation of only $+0.6^{\circ} \mathrm{C}$. The first month of autumn exceeded the multiannual average with only $+0.7^{\circ} \mathrm{C}$, being characterized as normal, after this month followed two warm months: October with a deviation of $+2.1^{\circ} \mathrm{C}$ and December $+2.4^{\circ} \mathrm{C}$, and one warm month (November $+1^{\circ} \mathrm{C}$ ) compared to the average for 60 years. Regarding the precipitations recorded in 2017, January was excessively droughty, followed by February with normal rainfall regime. The spring months of March and April were rainy, the month of May had few precipitations and was characterized as being normal. The summer months June and August were deficient in precipitation, but in July, September and October they exceeded the multiannual average with $+33.1 \mathrm{~mm},+13.7 \mathrm{~mm}$ and $+13.6 \mathrm{~mm}$ respectively, being characterized as very rainy. In November the rainfall exceeded the multiannual value by only $+2.3 \mathrm{~mm}$.

Atypical climatic conditions were registered in the agricultural year 2018. Although in the most months the average temperatures exceeded the 62-year average, during the first nine months of the year, with the highest temperature was recorded on 01.06 .2018 , of $31.4^{\circ} \mathrm{C}$. The lowest temperature recorded was $-16^{\circ} \mathrm{C}$ on the first day of March. In January, the amount of precipitation was below the normal for this period. February experienced excessive precipitation level, a mostly in the form of rain. In March there was also recoded a high amount of precipitation but this time both as rain and snow $(40.9 \mathrm{~mm})$. The following spring months had lower precipitation values: $26.2 \mathrm{~mm}$ in April, respectively $56.8 \mathrm{~mm}$ in May. In June were registered higher levels of rainfall of $98.3 \mathrm{~mm}$, in July $85.7 \mathrm{~mm}$ and in August of $38.2 \mathrm{~mm}$. The autumn was drier.

The climate changes recorded, as well as the unpredictable ones from the future impose the judicial choice of the biological material which is going to be cultivated and the application of certain agrotechnical systems adequate to the new climate conditions.

Optimizing the soil tillage system for the autumn wheat crop must ensure the accumulation and conservtion in the soil of the entire quantity of water received from the rainfall during summer and autumn. It is known that during the last years the climate in the Transylvanian Plain has changed, with the increase of the annual average temperature as well as the non-uniformity of rainfall, that is why the agricultural technique applied must be adapted to more oscillating ecological conditions.

Following the determinations conducted during 2012-2018, regarding the moisture existing in the soil for the winter wheat crop, one can notice that there are certain differences among the soil tillage systems (Table 1).The water supply available to the wheat plants ( $\mathrm{Ra} \mathrm{m}^{3} / \mathrm{ha}$ ), determined at the depth of $0-50 \mathrm{~cm}$, recorded an average value of $540 \mathrm{~m}^{3}$ /ha in the NT compared to SC in the period 2016-2018 where Ra was determined to be only 533 $\mathrm{m}^{3} /$ ha with a difference of $7 \mathrm{~m}^{3} /$ ha in the favor of NT which has a significant positive influence on the retention and conservation of water in the soil.

Table 1. Average water reserve available to plants in two soil systems, 2012-2018

\begin{tabular}{lccc}
\hline \multicolumn{1}{c}{ Tillage system } & $\begin{array}{c}\text { Water reserve } \\
\mathbf{m}^{3} / \mathbf{h a}\end{array}$ & $\begin{array}{c}\text { Differences } \\
\text { NT-CS }\end{array}$ & Significance \\
\hline Classic (CS) & 533 & 0.0 & $\mathrm{Ct}$. \\
\hline No tillage (NT) & 540 & 7.0 & $*$ \\
\hline & $\mathrm{LSD}(p 5 \%)=4 ; \operatorname{LSD}(p 1 \%)=19 ; \operatorname{LSD}(p 0.1 \%)=86$. & \\
\hline
\end{tabular}

Table 2 shows the average Ra values registered, starting in March and until October, compared to the two soil cultivation systems for a period of seven years. The NT system evidenced by Ra values recorded, proved to be superior to CS in the eight months where the Ra determinations were conducted at 0-50 cm depth. In five of the seven experimental years NT system had a positive influence on the available water supply compared to CS, and only in 2013 and 2016 the NT displayed lower water status than CS. The accumulation and storage of water in the soil for a longer period of time is believed to occur easier in the NT due to the fact that in the absence of plowing, the capilary water circuit in the ground is not interrupted. The loss of moisture in the layer 0-50 cm during MayJune is higher when temperatures are higher than the multiannual average for this period, above $15.1^{\circ} \mathrm{C}$ in $\mathrm{May}$ of $2012,2013,2015,2017$ and 2018 and respectively above $17.9^{\circ} \mathrm{C}$ in June in all seven years of experimentation. 
Table 2. The interaction between tillage system $\times$ year on the average soil water status (m³ $\left./ \mathrm{ha}^{2}\right), 2012-2018$

\begin{tabular}{|c|c|c|c|c|}
\hline Tillage system/year & & $\begin{array}{c}\text { Water reserve } \\
\mathbf{m}^{3} / \mathbf{h a}\end{array}$ & $\begin{array}{c}\text { Differences } \\
\text { NT-CS }\end{array}$ & Significance \\
\hline Classic (CS) & \multirow{2}{*}{2012} & 231 & 0.0 & Ct. \\
\hline No tillage (NT) & & 240 & 9.5 & $*$ \\
\hline Classic (CS) & \multirow{2}{*}{2013} & 374 & 0.0 & Ct. \\
\hline No tillage (NT) & & 292 & -82.6 & 00 \\
\hline Classic (CS) & \multirow{2}{*}{2014} & 476 & 0.0 & Ct. \\
\hline No tillage (NT) & & 573 & 96.9 & $* *$ \\
\hline Classic (CS) & \multirow{2}{*}{2015} & 701 & 0.0 & Ct. \\
\hline No tillage (NT) & & 716 & 15.8 & $* *$ \\
\hline Classic (CS) & \multirow{2}{*}{2016} & 894 & 0.0 & $\mathrm{Ct}$. \\
\hline No tillage (NT) & & 782 & -112.7 & 00 \\
\hline Classic (CS) & \multirow{2}{*}{2017} & 568 & 0.0 & Ct. \\
\hline No tillage (NT) & & 683 & 114.3 & $* *$ \\
\hline Classic (CS) & \multirow{2}{*}{2018} & 483 & 0.0 & Ct. \\
\hline No tillage (NT) & & 496 & 12.3 & $*$ \\
\hline & & $3 ; \operatorname{LSD}(\mathrm{p} 1 \%)=$ & $0.1 \%)=118$ & \\
\hline
\end{tabular}

According to the research conducted by Şimon et al., (2018) the current moisture reserve from the soil recorded at 0-50 cm deep is higher after conservative soil tillage systems, with a significant difference of $11.5 \mathrm{~m}^{3} / \mathrm{ha}$ was observed in the case of minimum tillage system compared to the classical soil tillage system.

A stress factor that affects the wheat yield considerably is represented by the heat during the spike formation period and that of the seed filling. A period that coincides approximately with the month of June in the area of Turda. In all of the experimental years the June average was higher $\left(18.5-21^{\circ} \mathrm{C}\right)$ comparative with the multiannual average $\left(17.9^{\circ} \mathrm{C}\right)$.

From Table 4, it can be seen that out of all seven years studied, a significantly positive influence is attributed to the NT system in the years 2013 and 2016 which were favorable to the yield of wheat compared to CS with a difference ranging between $152-190 \mathrm{~kg} / \mathrm{ha}$. A less favorable influence on yield formation can be attributed to the NT system in 2013 (4795 kg/ha) and 2016 (7046 kg/ha) with a significantly negative influence on the production of wheat. In the years 2012, 2014, 2015, 2018, the yield obtained in the two soil systems had very close values, the differences were low (7-67 kg/ha) and were not statistically assured.

Table 3. The interaction between the factors tillage system $\times$ year on the grain yield, during 2012-2018

\begin{tabular}{|c|c|c|c|c|}
\hline Tillage system/year & & $\begin{array}{c}\text { Yield } \\
\text { kg ha-1 }^{-1}\end{array}$ & Differences & Significance \\
\hline Classic (CS) & \multirow{2}{*}{2012} & 4868 & 0.0 & Ct. \\
\hline No tillage (NT) & & 4875 & 7 & - \\
\hline Classic (CS) & \multirow{2}{*}{2013} & 4985 & 0.0 & Ct. \\
\hline No tillage (NT) & & 4795 & -190 & 0 \\
\hline Classic (CS) & \multirow{2}{*}{2014} & 7063 & 0.0 & Ct. \\
\hline No tillage (NT) & & 7129 & 66 & - \\
\hline Classic (CS) & \multirow{2}{*}{2015} & 7117 & 0.0 & Ct. \\
\hline No tillage (NT) & & 7184 & 67 & - \\
\hline Classic (CS) & \multirow{2}{*}{2016} & 7197 & 0.0 & Ct. \\
\hline No tillage (NT) & & 7046 & -152 & 0 \\
\hline Classic (CS) & \multirow{2}{*}{2017} & 6078 & 0.0 & Ct. \\
\hline No tillage (NT) & & 6183 & 105 & $*$ \\
\hline Classic (CS) & \multirow{2}{*}{2018} & 5869 & 0.0 & Ct. \\
\hline No tillage (NT) & & 5882 & 13 & - \\
\hline
\end{tabular}




\section{CONCLUSIONS}

A stress factor that affects the yield is represented by the heat during the interval end of May - end of June, in the Turda area. In the all-experimental years, the month average temperature was higher in May $\left(15.7-18.7^{\circ} \mathrm{C}\right)$ compared with the multiannual average $\left(15.1^{\circ} \mathrm{C}\right)$, except for the years $2014\left(15.1^{\circ} \mathrm{C}\right)$ and $2016\left(14.3^{\circ} \mathrm{C}\right) . \mathrm{Al}$ experimental years presented higher temperatures in June compared to the multiannual average $\left(17.9^{\circ} \mathrm{C}\right)$.

In the NT system, the soil water status was higher even during drought, and water retained at higher depth is rising through capillaries to the radicular area compensating the lack of water due to drought.

In general, the yield achieved in the two soil systems (classic and no tillage) had very close values, the differences were only 7-67 kg/ha and not statistically significant.

Author Contributions: F.C. and C.C. conceived and designed the analysis, collected the data, performed the analysis and wrote the paper.

Funding Source: This work was supported by a grant of the Romanian Ministry of Research and Innovation, CCCDIUEFISCDI, PN-III-P1-1.2-PCCDI-2017-0056, Functional collaboration model between public research organizations and the economic environment for the provision of high-level scientific and technological services in the field of bio economy, within PNCDI III.

\section{Conflicts of Interest}

The authors declare that they do not have any conflict of interest.

\section{REFERENCES}

1. ARDS Turda (2008) ARDS Turda 50th Anniversary, Publishing House Ela Design; Turda.

2. Bogdan I, Gus P, Rusu T (2007) Research concerning weed control in maize. Agronomics Researches in Moldova; 1(129): 15-21.

3. Chețan F, Rusu T, Chețan C, Moraru PI (2016) Influence of soil tillage upon weeds, production and economic efficiency of corn crop. AgroLife Scientific Journal; 5(1): 36-43.

4. Cociu AI (2011) Contributions to the foundation, realization and development of viable sustainable and sustainable technologies based on conservative agriculture. AN. I.N.C.D.A. Fundulea; Vol. LXXIX, number l: 121129.

5. Guș P (1983) Agricultural and experimental technique. Cluj-Napoca: Tipo Agronomia.

6. Ibanez JJ, Effland WR, Krasilnikov PV, Cacovean H, Rusu T (2008) Pedo-diversity analysis and soil conservation. The 5th International Symposium Soil Minimum Tillage System, p: 134-154. Cluj-Napoca: Risoprint Publishing House.

7. MESP (1987) Pedologic Studies Elaboration Methodology. Pedologic and Agrochemical Ins. Bucharest. Vol. 1-3.

8. Meteorological Station of ARDS Turda, situated $23^{\circ} 47^{\prime}$ longitude; $46^{\circ} 35^{\prime}$ latitude; $427 \mathrm{~m}$ altitude.

9. Moraru PI, Rusu T (2010) Soil tillage conservation and its effect on soil organic matter, water management and carbon sequestration. Journal of Food, Agriculture \& Environment; 8 (3-4), 309-312.

10. Phillips RE, Phillips SH (1984) No-tillage agriculture, Principles and Practices. Publishing House Van Nostrand Reinhold Company Inc., 0-422-27731-8.

11. PoliFact (2015) ANOVA and Duncan's test pc program for variant analyses made for completely randomized polifactorial experiences. USAMV Cluj-Napoca.

12. Pop AI, Gus P, Rusu T, Bogdan I, Moraru PI (2013) The economic efficiency of the soybean culture depending on the soil tilling system and the pre-emerging plant. ProEnvironment; 6(14): 171-174.

13. Rusu T (2005) Agricultural technique. Cluj-Napoca: Risoprint Publishing House.

14. Rusu T, Moraru PI, Coste C, Cacovean H, Chețan F, Chetan C (2014) Impact of climate change on climatic indicators in Transylvanian Plain, Romania. Journal of Food, Agriculture \& Environment; 12(1): 469-473.

15. Şimon A, Rusu T, Cheţan F, Cheţan C, Moraru PI (2018) Impact of minimum tillage systems in conservation of water in the soil in the case of pea crops. AgroLife Scientific Journal; 7(1).

16. SRTS (2012) Romanian System of Soil Taxonomy. Bucharest: Publishing House Estfalia. 